\title{
PARAOXONASE 1 GENE POLYMORPHISMS CONTRIBUTE TO CORONARY ARTERY DISEASE RISK AMONG NORTH INDIANS
}

\author{
S. AGRAWAL, GAURAV TRIPATHI, R. PRAJNYA, NAKUL SINHA ${ }^{1}$, A. GILMOUR ${ }^{2}$, L. BUSH ${ }^{2}$, \\ S. MASTANA ${ }^{2}$
}

\section{ABSTRACT}

BACKGROUND: Polymorphisms in paraoxonase 1 (PON 1) coding for PON 1 enzyme have been studied as genetic markers of coronary artery disease (CAD). PO N 1 Q 192R and PON 1 L55M polymorphisms have been analyzed extensively, but data on association and role of these polymorphisms in the etiology of CAD are conflicting. In this study, we tested the genetic association between PON 1 Q 192R and PON 1 L55M polymorphisms and CAD among north Indians. MATERIALS AND METHODS: Tw o hundred eighty-five angiographically proven patients with coronary artery disease and 200 sex-matched and ethnically matched controls were genotyped for 2 PON 1 polymorphisms by the polymerase chain reaction-restriction fragment length polymorphism (PCR-RFLP) technique. Genotype/ allele frequencies were compared in patients and controls using the chi-square test. RESULTS: At PON 1-192 locus, there were significant differences between patients and controls $(P<0.05)$, leading to significant odds ratios for RR genotype $(\mathrm{OR}=1.92, \mathrm{Cl}: 1.19-3.10)$ and $* \mathrm{R}$ allele $(\mathrm{OR}=1.30, \mathrm{Cl}: 1.00-1.70)$. These odds ratios were higher in the sub-sample of smokers (2.84 and 1.45, respectively). Binary logistic regression analysis also confirmed that $* R$ allele carriers ( $Q R$ and $R R$ ) have a higher risk of CAD (OR=3.54, Cl: 1.67-5.53). PON 1-55 locus did not show significant differences between patients and controls, but LL genotype and ${ }^{*} \mathrm{~L}$ allele were significant risk factors in the nonsmoker group. RL haplotype was also significantly associated with CAD risk ( $O R=1.44, \mathrm{Cl}: 1.08-1.93)$. CONCLUSIONS: PON 1-192R allele and RR genotype are significantly associated with CAD patients from the north Indian population (Uttar Pradesh). This association was stronger in smokers, supporting the conclusion that an interaction between PON 1 activity and smoking augments CAD risk. Further studies with larger sample size are warranted to confirm these associations in different Indian populations.

Key words: Aryldialkylphosphatase, coronary artery disease, genetic, genetic predisposition to disease, genetics, genotype, human, polymorphism, PON 1 protein

DOI: $10.4103 / 0019-5359.55884$

Departments of Medical Genetics and ${ }^{1}$ Cardiology,

Sanjay Gandhi Postgraduate Institute of Medical

Sciences, Lucknow, India, ${ }^{2}$ Human Genetics Lab.,

School of Sport, Exercise and Health Sciences,

Loughborough University, Loughborough, UK

\section{Correspondence:}

Dr. Sarabjit Mastana, Human Genetics Lab.,

School of Sport, Exercise and Health Sciences, Loughborough

University, Loughborough, LE11 3TU, UK

E-mail: s.s.mastana@lboro.ac.uk

\section{INTRODUCTION}

Coronary artery disease (CAD) is a common, complex and multifactorial disorder and has become a major source of morbidity and mortality in different parts of the world. ${ }^{[1-6]}$ Genetic susceptibility to CAD 
involves contribution of many genes involved in the metabolic pathways in the pathogenesis of atherosclerosis. ${ }^{[2-3]}$ The prevalence of CAD varies widely among different geographical regions and ethnic groups. In urban India, the CAD rate is fourfold as compared to the rate in USA, ${ }^{[5]}$ and it has become a prominent health problem in India. ${ }^{[6]}$ Association and genome-wide studies have identified many candidate genes for CAD. ${ }^{[2]}$ Some of these genes have been examined in Indian populations, including APOE, APOA1, GSTs, ACE, CCR5, TNF $\alpha$, interleukins and CD14. ${ }^{[7-13]}$

Paraoxonase 1 (PON1), a calcium-dependent antioxidant glycoprotein, is synthesized in the liver and secreted into the plasma, where it is associated with high density lipoproteins (HDL). Paraoxonase enzyme (EC 3.1.8.1) is implicated in lipid metabolism and in the elimination of carcinogenic lipid-soluble radicals. ${ }^{[14]}$ PON1 is coded by the HUMPONA gene located on the chromosome 7 (7q 21.3-22.1). ${ }^{[15]}$ Paraoxonase protects both low density lipoprotein (LDL) and HDL from oxidation. It prevents the formation of oxidized LDL (ox-LDL) and inactivates LDL-derived oxidized phospholipids and prevents oxidation of HDL phospholipids. Two coding polymorphisms of this gene - codon 192 and codon 55 - have been studied for their association with CAD. At PON1-55, leucine is replaced by methionine (55L $>M)$; and at PON1-192, glutamine is replaced by arginine $(192 \mathrm{Q}>\mathrm{R})$. The $55 \mathrm{~L}>\mathrm{M}$ variant modulates $P O N 1$ concentration and level, and the Q192R variant is responsible for its catalytic activity. PON1-192 polymorphism gives rise to two alloenzymes: $Q$ and R. QQ- and RR-homozygous individuals demonstrate lower- and higher-activity PON1 respectively.[16-18] The PON1-Q192R polymorphism affects PON1 activity towards paraoxon, diazoxon, soman and sarin and is associated with coronary artery disease, stroke, familial hypercholesterolemia and type 2 diabetes. ${ }^{[14-23]}$ Some studies document that PON1-192 is involved in CAD risk only when other factors like diabetes, smoking and diet are present (19-23). Sanghera et al. ${ }^{[24,25]}$ reported that the PON1-192* $\mathrm{R}$ allele is a risk factor for coronary heart disease (CHD) among Asian Indians in Singapore. Pati and Pati ${ }^{[26]}$ reported a higher frequency of the $Q R$ and $R R$ genotypes among Indian CAD patients.

The aim of the present study was to analyze genetic variation at the PON1-192 and PON155 loci and to assess their genetic association with CAD in a north Indian population (Uttar Pradesh). This is a part of ongoing genetic investigations to untangle the genetic architecture of heart diseases in north India.

\section{MATERIALS AND METHODS}

\section{Study design and population}

Two hundred eighty-five angiographically proven CAD patients were included in the study. These patients were evaluated at the Department of Cardiology, and an experienced cardiologist performed all angiographic evaluations. Two hundred sex-matched healthy individuals from the institute staff were selected as controls after a detailed evaluation of history; clinical features; and investigations, including a treadmill test; to exclude presence of CAD. Controls with risk factors like family history of $C A D$, diabetes mellitus, hypertension and hyperlipidemia were excluded from the study. 
Lipid profile included total cholesterol (TC), triglycerides (TG), high-density lipoprotein (HDL) cholesterol and very low density lipoprotein cholesterol (VLDL), which were measured by the enzymatic method (chemistry autoanalyzer, Technicon RX-XT) both in the patient and control groups. The controls and patients were ethnically matched. Ethnicity was confirmed by detailed questionnaire, and only those participants who were settled in Uttar Pradesh for the last 5 generations were included in the study. Genders of controls and patients were also matched; there were comparable numbers of males and females in both categories. Informed written consent was obtained from all subjects. The study protocol conforms to the ethical guidelines of the 1975 Declaration of Helsinki. Ethical clearance was obtained following guidelines set down by the institute's (SGPGIMS) ethical committee.

\section{Angiographic classification}

Angiographic criteria defining CAD cases were as follows: (1) lumen reduction $\geq 20 \%$ on one or more major epicardial coronary arteries; (2) lumen reduction $10 \%-19 \%$ in 3 or more coronary artery segments. Mild coronary lesions were defined as $<50 \%$ lumen narrowing; and moderate-to-severe coronary artery stenoses, $\geq 50 \%$ lumen narrowing.

\section{Genotyping}

Genomic DNA was extracted from whole blood using the salting-out method. PCR was used to amplify two loci of the PON1 gene from 100ng genomic DNA in a total reaction volume of $20 \mu \mathrm{L}$, as described by Humbert et al. ${ }^{[16]}$ and Sanghera et al. ${ }^{[25]}$ The PCR was carried out with 2xReddyMix ${ }^{\mathrm{TM}}$ PCR Master Mix (Abgene) which contained $1.25 \mathrm{U}$ Thermoprime Plus
DNA polymerase, $75 \mathrm{mM}$ Tris- $\mathrm{HCl}(\mathrm{pH}, 8.8$ at $\left.25^{\circ} \mathrm{C}\right), 20 \mathrm{mM}\left(\mathrm{NH}_{4}\right)_{2} \mathrm{SO}_{4}, 2.5 \mathrm{mM} \mathrm{MgCl}{ }_{2}$, $0.01 \%(v / v)$ Tween $® 20,0.2 \mathrm{mM}$ each of dATP, dCTP, dGTP, dTTP precipitant and red dye for electrophoresis. Gel electrophoresis was carried out in $3 \%$ agarose gel. Alleles were scored independently by 2 researchers. Some samples ( $3 \%, 10$ patients and 5 controls) failed to amplify even after 3 attempts; therefore, these were not included in further analyses.

\section{Statistical analysis}

The Student $t$ test was used to compare means for continuous variables. The chisquare test was used to assess the HardyWeinberg equilibrium. The odds ratios with 95\% confidence intervals were calculated using standard epidemiological/ association methods, and significance was assessed by the chi-square test. All $P$ values are two tailed, and $P$ values $<.05$ were considered statistically significant. To evaluate the synergistic effect of PON1 $(-192,-55)$ gene polymorphisms and risk of CAD, we performed the multivariate analysis using the SPSS software (version 11.5). Allele frequencies were calculated as the number of occurrences of the test allele in the population divided by the total number of alleles. The carriage rate was calculated as the number of individuals carrying at least one copy of the test allele divided by the total number of individuals. Bonferroni correction was used to correct the level of significance. The sample size calculations showed that the present sample had enough power $(>80 \%$ ) to detect an odds ratio of around 1.5 or higher at alpha level of $5 \%$. This was based on distribution of allele frequencies in previous studies. The haplotype frequency estimation was evaluated by using Arlequin version 3.1 software. 


\section{RESULTS}

Demographic and clinical characteristics of patients and controls

Patients and controls were evaluated for 13 parameters as shown in Table 1. CAD patients Table 1: Demographic profile and clinical characteristics of coronary artery disease patients and controls

\begin{tabular}{|c|c|c|c|}
\hline Parameters (SI) & $\begin{array}{r}\text { Patients }=285 \\
(\text { Mean } \pm S D)\end{array}$ & $\begin{array}{c}\text { Controls }=200 \\
(\text { Mean } \pm S D)\end{array}$ & $P$ Value \\
\hline Age (Years) & $47.49 \pm 11.86$ & $44.58 \pm 13.36$ & $0.012^{*}$ \\
\hline Gender (male/female) & $244 / 41$ & $163 / 37$ & 0.276 \\
\hline Smokers (Yes/No) & $183 / 102$ & $105 / 95$ & $0.013^{*}$ \\
\hline Diet (Non-veg/veg) & $162 / 123$ & $95 / 105$ & 0.053 \\
\hline Hypertensive (No/Yes) & $193 / 92$ & $200 / 0$ & $\ldots \ldots$ \\
\hline Non-MI/MI & $204 / 81$ & $200 / 0$ & $\ldots .$. \\
\hline \multicolumn{4}{|l|}{ S. Glucose (F) } \\
\hline$(\mathrm{mg} / \mathrm{dL})$ & $99.4 \pm 26.3$ & $81.8 \pm 6.7$ & $<0.0001^{*}$ \\
\hline S. TG (mg/dL) & $207.09 \pm 108.9$ & $139.64 \pm 60.84$ & $<0.0001^{*}$ \\
\hline S. TC (mg/dL) & $172.79 \pm 48.83$ & $135.11 \pm 31.19$ & $<0.0001^{*}$ \\
\hline S. HDL (mg/dL) & $32.34 \pm 12.71$ & $40.83 \pm 7.14$ & $<0.0001^{*}$ \\
\hline S. LDL (mg/dL) & $103.26 \pm 43.42$ & $80.89 \pm 24.26$ & $<0.0001^{*}$ \\
\hline S. VLDL (mg/dL) & $40.81 \pm 17.49$ & $28.89 \pm 12.39$ & $<0.0001^{*}$ \\
\hline ApoB (mg/dL) & $156.23 \pm 41.88$ & $109.29 \pm 45.65$ & $<0.0001^{*}$ \\
\hline
\end{tabular}

${ }^{*}$ Significant value $(P<0.05)$ were significantly older than the controls $(P=0.012)$. Two most important parameters, viz., serum HDL level and $A p o B$, showed significant differences $(P<0.0001)$ between the two groups; however, total cholesterol, TG, LDL and VLDL ( $\mathrm{mg} / \mathrm{dL})$ were also significantly higher among the patients $(P<0.0001)$. The number of smokers in the patient group was greater when compared with that in the control group $(P<0.01)$.

There were no departures from the HardyWeinberg equilibrium at either of the loci in any group. Table 2 describes the distribution of genotypes and allele frequencies and associated odds ratios with confidence intervals. It is clear that PON1-192 RR genotype and ${ }^{*} R$ allele are significantly associated with CAD risk among north Indians. Susceptible LL genotype and *L allele of PON1-

Table 2: Distribution of genotype and allele frequency of PON1-192 and PON1-55 polymorphisms in patients and controls

\begin{tabular}{|c|c|c|c|c|}
\hline $\begin{array}{l}\text { Genotype } \\
\text { PON1-192 Q/R }\end{array}$ & Patients & Controls & $P$ Value & OR $(95 \% \mathrm{Cl})$ \\
\hline \multicolumn{5}{|l|}{ Genotype Frequency } \\
\hline $\mathrm{n}$ & 275 & 195 & & \\
\hline$Q Q$ & 74 (26.9) & $58(29.7)$ & 0.56 & $0.87(0.58-1.31)$ \\
\hline QR & $132(48.0)$ & $108(55.4)$ & 0.14 & $0.74(0.51-1.08)$ \\
\hline $\mathrm{RR}$ & $69(25.1)$ & $29(14.9)$ & $0.01^{*}$ & $1.92(1.19-3.1)$ \\
\hline \multicolumn{5}{|l|}{ Allele Frequency } \\
\hline Q allele & $280(50.9)$ & $224(57.4)$ & $0.048^{*}$ & $1.30(1.00-1.7)$ \\
\hline $\mathrm{R}$ allele & $270(49.1)$ & $166(42.6)$ & & \\
\hline \multicolumn{5}{|c|}{ Allele Carriage Frequency } \\
\hline Q allele carriage & $206(74.9)$ & $166(85.1)$ & $0.010^{*}$ & $0.52(0.32-0.84)$ \\
\hline $\mathrm{R}$ allele carriage & $201(73.1)$ & $137(70.3)$ & 0.569 & $1.15(0.77-1.73)$ \\
\hline \multicolumn{5}{|l|}{ PON1-55 L/M } \\
\hline \multicolumn{5}{|l|}{ Genotype Frequency } \\
\hline $\mathrm{n}$ & 279 & 190 & & \\
\hline LL & $158(56.6)$ & $94(49.5)$ & 0.140 & $1.34(0.93-1.95)$ \\
\hline LM & $96(34.4)$ & $74(39.0)$ & 0.350 & $0.83(0.56-1.21)$ \\
\hline MM & $25(9.0)$ & $22(11.5)$ & 0.441 & $0.75(0.41-1.38)$ \\
\hline \multicolumn{5}{|l|}{ Allele Frequency } \\
\hline L allele & $412(73.8)$ & $262(68.9)$ & 0.119 & $1.27(0.95-1.69)$ \\
\hline $\mathrm{M}$ allele & $146(26.2)$ & $118(31.1)$ & & \\
\hline \multicolumn{5}{|c|}{ Allele Carriage Frequency } \\
\hline L allele carriage & $254(91.1)$ & $168(88.4)$ & 0.441 & $0.75(0.41-1.38)$ \\
\hline $\mathrm{M}$ allele carriage & $121(43.4)$ & $96(50.5)$ & 0.152 & $1.33(0.92-1.93)$ \\
\hline
\end{tabular}

${ }^{*}$ Significant value $(P<.05)$ 
Table 3: Combined analysis of PON1 genotypes among coronary artery disease patients and controls (genotype and haplotype distribution)

\begin{tabular}{lcccc}
\hline Genotype & Patients $(n=269)$ & Controls $(n=186)$ & $P$ Value & OR $(95 \% \mathrm{Cl})$ \\
\hline PON1-192 Q/R and PON1-55 L/M (Genotype distribution) & & & & \\
QQ/LL & $37(13.7)$ & $27(14.5)$ & 0.93 & $0.94(0.55-1.60)$ \\
QQ/LM & $32(11.9)$ & $24(12.9)$ & 0.86 & $0.91(0.52-1.60)$ \\
QQ/MM & $4(1.5)$ & $2(1.1)$ & 0.97 & $1.39(0.25-7.66)$ \\
QR/LL & $78(29.0)$ & $52(28.0)$ & 0.89 & $1.05(0.70-1.59)$ \\
QR/LM & $40(14.9)$ & $40(21.5)$ & 0.09 & $0.64(0.39-1.04)$ \\
QR/MM & $11(4.1)$ & $14(7.5)$ & 0.17 & $0.52(0.23-1.18)$ \\
RR/LL & $36(13.4)$ & $13(7.0)$ & $0.04^{*}$ & $2.06(1.06-3.99)$ \\
RR/LM & $21(7.8)$ & $08(4.3)$ & 0.19 & $1.88(0.82-4.35)$ \\
RR/MM & $10(3.7)$ & $06(3.2)$ & 0.98 & $1.16(0.41-3.24)$ \\
PON1-192 Q/R and PON1-55 L/M (Haplotype distribution) & & & & \\
QL & $38 \%$ & $41 \%$ & 0.32 & $0.87(0.67-1.43)$ \\
RL & $35 \%$ & $27 \%$ & $0.01^{*}$ & $1.44(1.08-1.93)$ \\
QM & $13 \%$ & $16 \%$ & 0.27 & $0.80(0.55-1.77)$ \\
RM & $14 \%$ & $16 \%$ & 0.40 & $0.85(0.58-1.23)$ \\
\hline
\end{tabular}

*Significant value $(P<0.05)$

Table 4: Logistic regression analysis of determinants of coronary artery disease in patients

\begin{tabular}{lcc}
\hline Variables & $P$ Value & OR $(95 \%$ Cl) \\
\hline Age (years) & $0.0111^{*}$ & $2.56(1.31-4.62)$ \\
Sex (M/F) & $<0.0001^{*}$ & $4.09(2.83-6.43)$ \\
Smoking (Yes/No) & 0.0847 & $1.73(1.32-4.12)$ \\
Alcohol (Yes/No) & $<0.0001^{*}$ & $4.93(3.34-7.02)$ \\
HDL (mg/dL) & $0.0152^{*}$ & $2.45(1.51-3.42)$ \\
LDL(mg/dL) & 0.0782 & $0.29(0.14-0.33)$ \\
TG(mg/dL) & 0.3171 & $1.01(0.57-2.34)$ \\
TC(mg/dL) & 0.7594 & $0.31(0.12-1.14)$ \\
ApoB (mg/dL) & $0.0472^{*}$ & $1.99(0.67-3.01)$ \\
Non-Ml / MI & 0.0568 & $0.17(0.12-1.14)$ \\
VLDL(mg/dL) & 0.1009 & $1.65(0.61-2.59)$ \\
Hypertension (Yes/No) & 0.9089 & $0.11(0.10-1.11)$ \\
PON1-192 (QQ vs. QR+RR) & $0.005^{*}$ & $3.54(1.67-5.53)$ \\
PON1-55 (LL vs. LM+MM) & 0.2596 & $1.13(0.93-1.97)$ \\
\hline
\end{tabular}

*Significant value $(P<0.05)$

55 locus showed higher odds ratios but failed to achieve statistical significance.

Table 3 outlines the combined analysis of PON1-192 and PON1-55 genotypes and haplotype frequencies, along with associated odds ratios and $P$ values. It is clear from this table that individuals with a genetic constitution of RR/ LL genotype have 2 times higher risk of CAD compared to other genotype combinations. Similarly, RL haplotype is significantly associated with the disease. Other genotype and haplotype combinations failed to achieve statistical significance even though odds ratios were higher, possibly due to small observed numbers in some cells. Caution is warranted in interpretations of these results.

To demonstrate an independent role of PON1 in influencing the risk of CAD, we have assessed the association between PON1 genotypes and CAD risk using a multivariate model. In multivariate logistic regression analysis where CAD was a dependent variable and the two polymorphisms were independent variables, the PON1-192Q/R polymorphism revealed an association with CAD $(P=0.005)$, whereas the PON1-55L/M polymorphism association was not significant $(P=0.2596)$ [Table 4]. Age, sex, alcohol consumption and HDL and ApoB concentrations were the other independent factors for CAD susceptibility in this population.

To assess if there was any interaction between smoking and PON1 polymorphisms, we classified genotypes according to smoking/ nonsmoking status and assessed the associated odds ratios; the results are 
Table 5: Effect of PON1 (-192 and -55) genotypes on risk of CAD among smokers and nonsmokers

\begin{tabular}{|c|c|c|c|c|c|}
\hline \multicolumn{6}{|l|}{ Smokers } \\
\hline$\overline{P O N 1-192 Q / R}$ & Patients (\%) & Controls (\%) & $P$ Value & $O R$ & $95 \% \mathrm{Cl}$ \\
\hline $\mathrm{n}$ & 177 & 100 & & & \\
\hline $\mathrm{QQ}$ & 53 (29.9) & $33(33.0)$ & 0.69 & 0.87 & $(0.51-1.47)$ \\
\hline QR & 78 (44.1) & $56(56.0)$ & 0.07 & 0.62 & (0.38-1.01) \\
\hline $\mathrm{RR}$ & $46(26.0)$ & $11(11.0)$ & $0.005^{\star}$ & 2.84 & $(1.40-5.78)$ \\
\hline${ }^{*} \mathrm{Q}$ & $184(52.0)$ & $122(61.0)$ & 0.05 & 1.45 & $(1.02-2.06)$ \\
\hline${ }^{*} \mathrm{R}$ & $170(48.0)$ & $78(39.0)$ & & & \\
\hline \multicolumn{6}{|l|}{ PON1-55 L/M } \\
\hline $\mathrm{n}$ & 180 & 102 & & & \\
\hline LL & $97(53.8)$ & 57 (55.9) & 0.84 & 0.92 & $(0.57-1.50)$ \\
\hline LM & 66 (36.7) & $33(32.3)$ & 0.58 & 1.21 & $(0.72-2.02)$ \\
\hline MM & $17(9.4)$ & $12(11.8)$ & 0.68 & 0.78 & (0.36-1.71) \\
\hline${ }^{*} \mathrm{~L}$ & $260(72.2)$ & $147(72.1)$ & 0.95 & 1.01 & $(0.69-1.48)$ \\
\hline${ }^{*} \mathrm{M}$ & $100(27.8)$ & $57(27.9)$ & & & \\
\hline \multicolumn{6}{|l|}{ Nonsmokers } \\
\hline PON1-192 Q/R & Patients & Controls & P Value & OR & $95 \% \mathrm{Cl}$ \\
\hline $\mathrm{n}$ & 98 & 95 & & & \\
\hline $\mathrm{QQ}$ & $21(21.4)$ & 25 (26.3) & 0.53 & 0.76 & $(0.39-1.48)$ \\
\hline QR & 54 (55.1) & $52(54.8)$ & 0.92 & 1.01 & (0.58-1.79) \\
\hline $\mathrm{RR}$ & $23(23.5)$ & $18(18.9)$ & 0.55 & 1.31 & $(0.66-2.63)$ \\
\hline${ }^{*} \mathrm{Q}$ & $96(49.0)$ & $102(53.7)$ & 0.41 & 1.21 & $(0.81-1.80)$ \\
\hline${ }^{*} \mathrm{R}$ & $100(51.0)$ & $88(46.3)$ & & & \\
\hline \multicolumn{6}{|l|}{ PON1-55 L/M } \\
\hline $\mathrm{n}$ & 99 & 88 & & & \\
\hline LL & $61(61.6)$ & $37(42.0)$ & $0.01^{*}$ & 2.21 & $(1.23-3.98)$ \\
\hline LM & 30 (33.3) & $41(46.6)$ & $0.03^{*}$ & 0.45 & $(0.27-0.89)$ \\
\hline $\mathrm{MM}$ & $8(8.1)$ & $10(11.4)$ & 0.61 & 0.57 & $(0.26-1.82)$ \\
\hline L & $152(76.8)$ & $115(65.3)$ & $0.02^{*}$ & 1.75 & $(1.11-2.76)$ \\
\hline$M$ & $46(23.2)$ & $61(34.6)$ & & & \\
\hline
\end{tabular}

*Significant value $(P<0.05)$

presented in Table 5. It is clear from the table that PON1-192 polymorphism provides higher odds ratios (compared to the combined one) at genotype level among smokers; but at allele level, this effect is not significant. At PON1-55 locus, there is no interaction with smoking; but among nonsmokers, LM genotype seems to be protective and $\mathrm{LL}$ genotype and ${ }^{\star} \mathrm{L}$ allele are susceptible.

\section{DISCUSSION}

Several previous studies have produced evidence to suggest that the PON1-192 and PON1-55 polymorphisms may be associated with $C A D$ risk in the general population, due to PON1 enzyme's role in lipid metabolism. However, this is the first study on these polymorphisms specifically on a homogenous population from north India to confirm and replicate the existence of a susceptible association between the PON1-192 and PON1-55 loci and CAD. These results are consistent with previous studies. Significant association between the PON1-192 R (Arg) allele and CAD risk has been detected in Asian Indians, ${ }^{[24,26]}$ North American Caucasians ${ }^{[27,28]}$ and the Japanese population, ${ }^{[20]}$ but not in Chinese, ${ }^{[24]}$ Korean, ${ }^{[29]}$ Spanish, ${ }^{[21]}$ Italian, ${ }^{[30]}$ British Caucasiann ${ }^{[22,31]}$ and Polish ${ }^{[32]}$ populations.

A meta-analysis of 43 genetic association studies conducted by Wheeler et al. ${ }^{[33]}$ found that the per-allele relative risk of the R192 variant to $\mathrm{CHD}$ was 1.12 (95\% Cl: $1.07-1.16)$, indicating a weak positive association. In the present study, odds ratios were slightly higher, suggesting that $192 \mathrm{R}$ associations may be 
stronger in specific populations, and our results are consistent with those of previous studies on Indian populations. ${ }^{[24,26]}$

PON1 protein plays a key role in organophosphate metabolism (widely used in insecticides and nerve gases); however, PON1 has been linked to lipid metabolism also. ${ }^{[34]}$ The link between PON1 activity and atherosclerosis is largely established by biological rather than epidemiological studies, as there is evidence that peroxidation of low-density lipoprotein cholesterol (LDL-C) is an important risk factor for atherosclerosis. ${ }^{[34-40]}$ As oxidative damage is a major contributor to arteriolosclerosis, the oxidative modification of LDL in the artery wall is an important factor in the development of CAD. Functional in vivo studies indicate that PON1 may prevent the development of CAD by being responsible for the ability of HDL to inhibit the oxidative modification of LDL particles into active atherogenic particles. ${ }^{[35,36]}$ HDL-associated PON1 has been shown to impede the oxidation of LDL by inhibiting the formation of lipid peroxides. ${ }^{[37]}$ The PON1-192 polymorphism may be associated with an increased CAD risk due to the $R$ (Arg) allele (high-activity $R$ isoform) being less efficient than the $Q(G \mid n)$ allele (low-activity $Q$ isoform) in reducing the oxidative modification of LDL, decreasing lipid peroxide hydrolysis. ${ }^{[14]}$ However, it has also been suggested that the quality of the PON1 enzyme may be a better predictor of CHD risk than the PON1 genotype; because as compared to controls, patients consistently demonstrate lower PON1 activity and concentration levels, regardless of their PON1 genotype. ${ }^{[38-41]}$

The PON1-55 polymorphism is not extensively studied among Indian populations, and the present study results are consistent with those of the previous study by Sanghera et al., ${ }^{[25]}$ suggesting that PON1-55 has no independent effect on CAD. However, the $L L$ and ${ }^{*} L$ allele are significantly associated with CAD among nonsmokers, which should be considered further with a large-population study. In the present study, haplotype combination $R / L$ has a significant susceptible effect, which is what one would expect in the light of the higher activity levels of these isoforms.

There appears to be a strong geneenvironment interaction in relation to the PON1-192 polymorphism and CAD. The environmental factors may mask or induce the atherogenic potential of the PON1-192 R (Arg) allele, thus modifying the effect of the PON1 gene on CAD risk. ${ }^{[42]}$ It is conceivable that the PON1-192 $R$ allele has a more exaggerated effect on CAD risk for those living in high-risk environments of enhanced oxidative stress, such as smokers and those maintaining adverse dietary habits. In relation to smoking, in the present study, a larger proportion of patients smoked in comparison to controls $(P<0.05)$. The odds ratios for $\mathrm{RR}$ genotype are relatively higher in smokers and do not achieve significance among nonsmokers. Cigarette smoke contains many free radicals, and smokers generally have a lower antioxidative capacity than nonsmokers. Therefore, oxidized LDL particles from smokers generate more lipid peroxidation products than LDL from nonsmokers. Thus, it is possible that PON1 activity has a more important protective role of lipid peroxidation in smokers than in nonsmokers. 
Other genetic factors that may explain the possible population-specific association between the PON1-192 R (Arg) allele and $C A D$ risk include linkage disequilibrium (LD) and gene-gene interactions. It has been suggested that the PON1 gene closely interacts with members of its structurally similar multigene family, PON2 and PON3, to modulate $\mathrm{CAD}$ risk at the gene level. ${ }^{[24,25]} \mathrm{A}$ populationspecific association may be explained through population differences in LD between the polymorphic sites of the PON genes, which arose through genetic drift or selective mechanisms. ${ }^{[29]}$ In an Asian Indian population, Sanghera et al. ${ }^{[24,25]}$ found $\mathrm{CHD}$ risk associated with the PON2* $S$ allele to be confined to PON1-192 R allele carriers. This suggests an interaction between the distributions of genotypes at the two genes, acting together in relation to atherogenic molecules, which should be explored in further studies. It is possible that observed CAD associations are due to LD of PON1 and PON2 with PON3 or another nearby gene. It is also possible that there is an active association between the different polymorphisms within the coding and promoter region of the PON1 gene.

The most obvious limitation of the present study is its sample size; though it had enough power to detect a moderate level of odds ratios of 1.5 or above, the allele frequency, ethnicity and subgrouping reduced the sample size to detect significant effects further. However, the sample was well characterized and was from a homogenous Indian population, which reduces the risks of population stratification and false associations.

When considered as a whole, the results of the present study on a north Indian population support and confirm the association of PON192 RR genotype and * $R$ allele with $C A D$ in the general and smoker populations. The PON1$55 \mathrm{LL}$ genotype and * $\mathrm{L}$ allele are significantly associated with CAD among nonsmokers, and susceptibility may be governed by different mechanisms at enzyme/ gene level. Further research is warranted on other populations from different parts of India to clarify if the PON loci are independent risk factors for CAD in the general - populations.

\section{REFERENCES}

1. Tobin MD, Braund PS, Burton PR, Thompson JR, Steeds R, Channer, et al. Genotypes and haplotypes predisposing to myocardial infarction: A multilocus case-control study. Eur Heart $\mathrm{J}$ 2004;25:459-67.

2. Samani NJ, Erdmann J, Hall AS, Hengstenberg C, Mangino M, Mayer B, et al. Genomewide association analysis of coronary artery disease. N Engl J Med 2007;357:443-53.

3. Ashavaid TF, Shalia KK, Kondkar AA, Todur SP, Nair KG, Nair SR. Gene polymorphism and coronary risk factors in Indian Populations. Clin Chem Lab Med 2002;40:975-85.

4. Hirashiki A, Yamada $Y$, Murase $Y$, Suzuki $Y$, Kataoka $\mathrm{H}$, Morimoto $\mathrm{Y}$, et al. Association of gene polymorphisms with coronary artery disease in low or high risk subjects defined by conventional risk factors. J Am Coll Cardiol 2003;42:1429-37.

5. Enas EA. Coronary artery disease epidemics in Indians: A cause for alarm and call for action. $J$ Indian Med Assoc 2000;98:697-702.

6. Singh RB, Tomlinson B, Thomas N, Sharma R. Coronary artery disease and coronary risk factors: The south Asian paradox. J Nutr Environ Med 2001;11:43-51.

7. Agrawal S, Singh VP, Tewari S, Sinha N, Ramesh $\mathrm{V}$, Agarwal $\mathrm{S}$, et al. Angiotensin-converting 
enzyme gene polymorphism in coronary artery disease in north India. Indian Heart J 2004;56: 44-6.

8. Girisha KM, Gilmour A, Mastana S, Singh VP, Sinha N, Tewari S, et al. T1 and M1 polymorphism in glutathione S-transferase gene and coronary artery disease in North Indian population. Indian J Med Sci 2004;58:520-6.

9. Sankar VH, Girisha KM, Gilmour A, Singh VP, Sinha N, Tewari S, et al. TNFR2 gene polymorphism in coronary artery disease. Indian J Med Sci 2005;59:104-8.

10. Banerjee I, Pandey U, Hasan OM, Parihar R, Tripathi V, Ganesh S. Association between inflammatory gene polymorphisms and coronary artery disease in an Indian population. J Thromb Thrombolysis 2009;27:88-94.

11. Rai TS, Khullar M, Sehrawat BS, Ahuja M, Sharma PK, Vijayvergiya R, et al. Synergistic effect between apolipoprotein $\mathrm{E}$ and apolipoprotein $\mathrm{A} 1$ gene polymorphisms in the risk for coronary artery disease. Mol Cell Biochem 2008;313:139-46.

12. Sharda S, Gilmour A, Harris V, Singh VP, Sinha $\mathrm{N}$, Tewari S, et al. Chemokine receptor 5 (CCR5) deletion polymorphism in North Indian patients with coronary artery disease. Int $\mathrm{J}$ Cardiol 2008;124:254-8.

13. Singh PP, Singh M, Bhatnagar DP, Kaur TP, Gaur SK. Apolipoprotein E polymorphism and its relation to plasma lipids in coronary heart disease. Indian J Med Sci 2008;62:105-12.

14. Mackness B, Mackness MI, Arrol S, Turkei W, Durrington PN. Effect of the human serum paraoxonase 55 and 192 genetic polymorphism on the protection by high density lipoprotein against low density lipoprotein oxidative modification. FEBS Lett 1998;423:57-60.

15. Primo-Parmo SL, Sorenson RC, Teiber J, La Du BN. The human serum paraoxonase / arylesterase gene (PON1) is one member of a multigene family. Genomics 1996;33:498-507.

16. Humbert R, Disteche CM, Hasset C, Omiecinski CJ, Furlong CE. The molecular basis of the human serum Paraoxonase activity polymorphism. Nat Genet 1993;3:73-6.

17. Senti M, Tomas M, Marrugat J, Elosua R. Paraoxonase 1-192 polymorphism modulates the nonfatal myocardial infarction risk associated with decreased HDLs. Arterioscler Thromb Vasc Biol 2001;21:415.

18. Scacchi R, Corbo RM, Rickards O, De Stefano, GF. New data on the world distribution of paraoxonase (PON1 192) gene frequencies. Hum Biol 2003;75:365-73.

19. Ruiz J, Blanche $H$, James RW, Blatter Garin MC, Vaisee C, Charpentier G, et al. Gln-Arg 192 polymorphism of Paraoxonase and coronary heart disease in type 2 diabetes. Lancet 1995;30:86972.

20. Odawara M, Tachi Y, Yamashita K. Paraoxonase polymorphism (GIn192Arg) is associated with coronary heart disease in Japanese Non insulin dependent diabetes mellitus. J Clin Endocr Metab 1997;82:2257-60.

21. Ferre N, Tous M, Paul A, Zamora A, Vendrell JJ, Bardaji A, et al. Paraoxonase Gln-Arg(192) and Leu-Met(55) gene polymorphisms and enzyme activity in a population with a low rate of coronary heart disease. Clin Biochem 2002;35:197-203.

22. Robertson KS, Hawe, E, Miller GJ, Talmud PJ, Humphries SE. Human Paraoxonase gene cluster polymorphisms as predictors of coronary heart disease risk in the prospective Nortwick Park Heart Study II. Biochem Biophysica Acta 2003;1639:203-12.

23. Pfohl M, Koch M, Enderle MD, Kuhn R, Fullhase J, Karsch KR, et al. Paraoxonase 192 Gln/Arg gene polymorphism, coronary artery disease, and myocardial infarction in type 2 diabetes. Diabetes 1999;48:623-7.

24. Sanghera DK, Saha N, Aston CE, Kamboh MI. Genetic polymorphisms of Paraoxonase and the risk of coronary heart disease. Arterioscler Thromb Vasc Biol 1997;17:1067-73.

25. Sanghera DK, Saha N, Kamboh MI. The codon 55 polymorphism in the paraoxonase 1 gene is not 
associated with the risk of coronary heart disease in Asian Indians and Chinese. Atherosclerosis 1998;136:217-23.

26. Pati N, Pati U. Paraoxonase gene polymorphism and coronary artery disease in Indian subjects. Int J Cardiol 1998;66:165-8.

27. Serrato $M$, Marian AJ. A variant of human paraoxonase/ arylesterase (HUMPONA) gene is a risk factor for coronary artery disease. J Clin Investig 1995;96:3005-8.

28. Bhattacharyya T, Nicholls SJ, Topol EJ, Zhang $\mathrm{R}$, Yang X, Schmitt D, et al. Relationship of paraoxonase 1 (PON1) gene polymorphisms and functional activity with systemic oxidative stress and cardiovascular risk. JAMA 2008;299:1265-76.

29. Hong SH, Song J, Min, WK, Kin, JK. Genetic variations of the Paraoxonase gene in patients with coronary artery disease. Clin Biochem 2001;34:475-81.

30. Ombres D, Pannitteri G, Montali A, Candeloro A, Seccareccia F, Campagna F, et al. The glnArg192 polymorphism of human paraoxonase gene is not associated with coronary artery disease in Italian patients. Arterioscler Thromb Vasc Biol 1998;18:1611-6.

31. Lawlor DA, Day IN, Gaunt TR, Hinks LJ, Briggs $\mathrm{PJ}$, Kiessling $\mathrm{M}$, et al. The association of the PON1 Q192R polymorphism with coronary heart disease: Findings from the British Women's Heart and Health cohort study and a meta-analysis. BMC Genet 2004;5:17.

32. Balcerzyk A, Zak I, Krauze J. Synergistic effects between Q192R polymorphism of paraoxonase 1 gene and some conventional risk factors in premature coronary artery disease. Arch Med Res 2007;38:545-50.

33. Wheeler JG, Keavney BD, Watkins H, Collins R, Danesh J. Four Paraoxonase gene polymorphisms in 11212 cases of coronary heart disease and 12 786 controls: Meta-analysis of 43 studies. Lancet 2004;363:689-95.
34. Mackness MI, Durrington PN, Ayub A, Mackness B. Low serum Paraoxonase: A risk factor for atherosclerotic disease? Chem Biol Interact 1999;119-120:389-97.

35. Mackness MI, Durrington PN. HDL: Its enzymes and its potential to influence lipid peroxidation. Atherosclerosis 1995;115:243-53.

36. Watson AD, Berliner JA, Hama SY, La Du BN, Faull KF, Fogelman AM, et al. Protective effect of high density lipoprotein associated paraoxonase: Inhibition of the biological activity of minimally oxidised low density lipoprotein. J Clin Investig 1995;96:2882-91.

37. Mackness MI, Arrol S, Durrington PN. Paraoxonase prevents accumulation of lipoperoxides in lowdensity lipoproteins. FEBS Lett 1991;286:152-4.

38. Mackness B, Davis GK, Turkie W, Lee E, Roberts $\mathrm{DH}$, Hill E, et al. Paraoxonase status in coronary heart disease are activity and concentration more important than genotype? Arterioscler Thromb Vasc Biol 2001;21:1451-7.

39. Mackness M, Mackness B. Paraoxonase 1 and atherosclerosis: Is the gene or the protein more important? Free Rad Biol Med 2004;37:1317-23.

40. Singh S, Venketesh S, Verma JS, Verma M, Lellamma CO, Goel RC. Paraoxonase (PON1) activity in North West Indian Punjabis with coronary artery disease and type 2 diabetes mellitus. Indian J Med Res 2007;125:783-7.

41. Sharma R, Singh B, Mahajan M. PON1 activity is inversely related to LDL apoB carbonyl content in patients with coronary artery disease. Kaohsiung J Med Sci 2007;23:225-31.

42. Sen-Banerjee S, Siles Z, Campos H. Tobacco smoking modifies association between Gln-Arg 192 polymorphism of human paraoxonase gene and risk of myocardial infarction. Arterioscler Thromb Vasc Biol 2000;20:2120-6.

Source of Support: Nil. Conflict of Interest: None declared. 